\title{
Pengaruh Pendidikan Kesehatan Terhadap Tingkat Pengetahuan Remaja Tentang Bahaya Pernikahan Dini Di Lombok Barat
}

\author{
Akmal Rosamali ${ }^{1}$, Dedy Arisjulyanto ${ }^{2}$ \\ Program Studi Magister Administrasi dan Kebijakan Kesehatan \\ Universitas Qamarul Huda Badaruddin ${ }^{1}$ \\ Larpa Institute ${ }^{2}$ \\ E-mail: rosamaliakmal@gmail.com
}

\begin{abstract}
Badan Kependudukan dan Keluarga Berencana (BKKBN) mengatur pengertian dan rentang usia remaja adalah 10-24 tahun dan belum menikah. Dan saat ini jumlah remaja Indonesia usia 10-24 tahun pada tahun 2017 sebanyak 67,36 juta atau sekitar 25\% dari jumlah penduduk Indonesia, angka pernikahan dini di NTB berada di atas angka nasional yaitu sebesar 31,12\%. Dan kasus pernikahan dini di NTB sangat tinggi yaitu 58,1\% dari total pernikahan di NTB. Tujuan penelitian ini adalah untuk mengetahui pengaruh pendidikan kesehatan terhadap peningkatan pengetahuan remaja tentang bahaya pernikahan dini. Penelitian ini menggunakan rancangan "Quasi Eksperimen Design”. Populasi dalam penelitian ini adalah remaja di Kabupaten Lombok Barat, dan menjadi sampel dalam penelitian ini 113 orang yang diambil dengan teknik sampling Purposive sampling. Hasil penelitian ini menunjukan perbedaan nilai rata-rata tingkat pengetahuan remaja sebelum dan sesudah diberikan pendidikan kesehatan, di dapat nilai nilai $p$-value $=0,000$ lebih kecil dari $\alpha=0,05$. Penelitian ini dapat disimpulkan bahwa ada perbedaan nilai tingkat pengetahuan remaja setelah diberikan pendidikan kesehatan. diharapkan hasil penelitian ini bisa menjadi dasar kebijakan di Kabupaten Lombok Barat.
\end{abstract}

\section{Keyword : Pendidikan Kesehatan, Pernikahan Dini, Remaja}

\section{LATAR BELAKANG}

Badan Kependudukan dan Keluarga Berencana (BKKBN) mengatur pengertian dan rentang usia remaja adalah 10-24 tahun dan belum menikah. Dan saat ini jumlah remaja Indonesia usia 10-24 tahun pada tahun 2017 sebanyak 67,36 juta atau sekitar $25 \%$ dari jumlah penduduk Indonesia dan merupakan tantangan besar bagi Indonesia dan harus lebih memperhatikan kelompok usia remaja, diantaranya adalah masalah kesehatan remaja (BKKBN, 2017).
Permasalahan-permasalahan kesehatan yang sering menjadi isu-isu sosial dan klinis yang beresiko bagi kesehatan reproduksi antara lain adalah masalah seks bebas, kehamilah yang tidak diinginkan, aborsi, infeksi menular seksual (IMS), HIV/AIDS, kekerasan seksual, Narkoba dan Napza serta masalah-masalah kurangnya pengetahuan tentang kesehatan reproduksi pada remaja (Kusmiran, 2014;Umaroh, Kusumawati, \& Kasjono, 2015).

Gambaran pengalaman hubungan seksual remaja usia $15-24$ sebanyak $2 \%$ pada perempuan pada laki-laki 8\% pada laki-laki. Perilaku seksual pada umur usia 17 tahun dengan presentasi 59\% wanita dan $74 \%$ pria pernah melakukan hubungan seksual pranikah. Dalam penelitian Salih (2015) sekitar Sekitar 17\% remaja yang pernah melakukan aktivitas seksual dengan lebih dari satu pasangan, dan $62 \%$ responden yang tidak menggunakan kondom selama melakukan perilaku seksual. 
Ramos et al., (2017) menyatakan mayoritas remaja pernah melakukan hubungan seks dan mereka juga menjelaskan terkait tidak terpenuhinya informasi tentang kesehatan reproduksi, kurangnya pengetahuan dan pendidikan kesehatan terkait kesehatan reproduksi sehingga remaja melakukan perilaku seksual pranikah yang dampaknya terjadi pernikah dini.

Pentingnya pemberian pendidikan kesehatan reproduksi dan kesehatan seksual remaja baik secara formal maupun non formal seperti yang dikemukakan oleh Suryoputro \& Widjanarko ( 2016) penting diadakannya suatu program pendidikan yang tepat dan komprehensif mengenai kesehatan seksual dan reproduksi yang dapat diperkenalkan melalui sekolah-sekolah, dan menurut Minguez (2015) dan Arisjulyanto, Ismail, \& Fuad (2019) pemberian pendidikan kesehatan merupakan salah satu upaya yang tepat dalam mengatasi bahaya pernikahan dini dan masalah-masalah kesehatan reproduksi remaja (Yulfitria, 2017;Finan, et al., 2018).

Data Badan Pusat Statistik (2017) menunjukan angka pernikahan dini di NTB berada di atas angka nasional yaitu sebesar 31,12 $\%$. Dan kasus pernikahan dini di NTB sangat tinggi yaitu 58,1\% dari total pernikahan di NTB, yang menjadi salah satu faktor penyebab perilaku seksual pranikah remaja, masalah ini juga diperparah dengan kurangnya pengetahuan remaja tentang bahaya perilaku seksual pranikah. Penelitian yang dilakukan oleh Arisjulyanto (2019) di Kabupaten Lombok Barat menyatakan 45,52\% remaja melakukan perilaku seksual berisiko, banyak faktor yang menyebabkan kejadian perilaku seksual pranikah berisiko antara lain adalah, intensitas penggunaan sosial media yang menjadi sumber terpaparnya pornografi, pengaruh temen sebaya, efikasi diri rendah hingga perilaku sex chat.
Berdasarkan Studi pendahuluan di Kabupaten Lombok Barat yang dilaksanakan dengan menggunakan teknik wawancara,dengan jumlah sampel 30 orang remaja, menunjukan bahwa masih kurangnya pengetahuan remaja tentang bahaya pernikahan dini,9 orang remaja berpengetahuan cukup, dan 21 orang remaja berpengetahuan kurang, sehingga perlunya diberikan pendidikan kesehatan bagi remaja di Lombok Barat.

Sihite, Nugroho, \& Dharmawan (2017) menyatakan ada pengaruh pendidikan kesehatan terhadap peningkatan pengetahuan remaja tentang seksualitas.

\section{METODE PENELITIAN}

Desain penelitian yang digunakan dalam penelitian ini adalah Quasi Eksperimen Design dengan teknik pengambilan sampel purposive sampling. Tujuan penelitian ini adalah melihat perbedaan tingkat pengetahuan remaja sebelum dan sesudah diberikan pendidikan kesehatan, Penelitian ini melakukan observasi dua kali yaitu sebelum dan sesudah diberikan pendidikan kesehatan. Tingkat pengetahuan remaja diukur 2 kali yaitu sebelum diberikan penyuluhan diberikan pendidikan kesehatan (pre-test) dan setelah diberikan pendidikan kesehatan (Posttest), dan jumlah sampel dalam penelitian ini sebanyak 113 responden.

\section{HASIL dan PEMBAHASAN}

Karakteristik Responden

Tabel 1. Karakteristik Responden

\begin{tabular}{lll}
\hline Variabel & $\begin{array}{l}\text { Jumlah } \\
\text { (n) }\end{array}$ & Persen(\%) \\
\hline Jenis kelamin & & \\
$\quad$ Laki-laki & 38 & 33,63 \\
$\quad$ Perempuan & 75 & 66,37 \\
Umur & & \\
15 tahun & 39 & 34,51 \\
16 tahun & 28 & 24,78 \\
17 tahun & 16 & 14,16 \\
18 tahun & 30 & 26.55 \\
Tinggal bersama & & \\
$\quad$ Orang tua & 97 & 85,84 \\
$\quad$ Wali & 16 & 14,16 \\
\hline
\end{tabular}


Berdasarkan Tabel 1 diketahui jumlah jenis kelamin terbanyak dalam penelitian ini adalah jenis kelamin wanita sebanyak $66,37 \%$ sedangkan laki-laki sebanyak 33,63\%. Usia tertinggi adalah usia 15 tahun $(34,51 \%)$, dan 85 $\%$ dari remaja tinggal bersana orang tua.

Tabel 2. Nilai Rata-Rata Tingkat Pengetahuan Remaja Tentang Bahaya Pernikahan Dini Sebelum dan Sesudah diberikan Pendidikan Kesehatan

\begin{tabular}{lcc}
\hline Variabel & Mean & n \\
\hline Pretest & 11,83 & 113 \\
Postest & 22,46 & 113 \\
\hline
\end{tabular}

Rata-rata tingkat pengetahuan remaja di Lombok Barat tentang bahaya pernikahan dini sebelum diberikan pendidikan kesehatan sebesar 11,83 atau kategorik pengetahuan kurang, dan mengalami peningkatan setelah diberikan intervensi menjadi 22,46.

Tabel 3. Pengaruh Pendidikan Kesehatan Terhadap Tingkat Pengetahuan Remaja Tentang Bahaya Pernikahan Dini

\begin{tabular}{lccccc}
\hline Variabel & Mean & $\mathrm{n}$ & CI 95\% & $\begin{array}{c}\mathrm{P} \\
\text { Value }\end{array}$ \\
\hline Pretest & 11,83 & 113 & 11.25 & - & \\
& & & 12.40 & 0,000 \\
Postest & 22,46 & 113 & 21.78 & - & \\
& & & 23.13 & &
\end{tabular}

Berdasarkan hasil uji statistik, dapat diperoleh nilai rata-rata tingkat pengetahuan remaja tentang bahaya pernikahan dini sebelum dan sesudah diberikan pendidikan kesehatan, nilai rata-rata tingkat pengetahuan remaja sebelum di berikan pendidikan kesehatan sebesar 11,83 dan nilai rata-rata tingkat pengetahuan remaja sesudah pemberian pendidikan kesehatan sebesar 22,46. Nilai rata-rata tingkat pengetahuan remaja menunjukan adanya peningkatan pengetahuan setelah diberikan pendidikan kesehatan sebesar 10,62 dengan $\mathrm{p}$ value 0,000 .

\section{Pembahasan}

Perbedaan tingkat pengetahuan remaja tentang bahaya pernikahan dini dipengaruhi oleh kurangnya paparan informasi tentang kesehatan reproduksi. banyak remaja yang tidak mendapatkan informasi kesehatan reproduksi orang tua, pendidikan di sekolah, maupun dari internet dan teman sebaya.

Hasil penelitian ini menunjukan ada perbedaan tingkat pengetahuan remaja tentang pernikah dini sebelum dan sesudah diberikan pendidikan kesehatan, dan mengalami peningkatan pengetahuan setelah diberikan pendidikan kesehatan sebesar 10,62 dengan $p$ value 0,000 , yang berarti ada pengaruh pendidikan kesehatan terhadap tingkat pengetahuan remaja tentang bahaya pernikahan dini.

Penelitian ini sejalan dengan penelitian yang dilkukan oleh Rizki (2012) yang menyatakan ada pengaruh pendidikan kesehatan terhadap tingkat pengetahuan remaja tentang kesehatan reproduksi. Dan didukung oleh penelitian Madinah, Rahfiludin, \& Nugraheni (2017) yang menyatakan ada pengaruh pendidikan kesehatan terhadap peningkatan pengetahuan remaja tentang peningkatan usia perkawinan. Penelitian ini sejalan dengan penelitian Bulahari \& Korah (2015) Faktor yang mempengaruhi pengetahuan remaja tentang kesehatan reproduksi dan bahaya pernikahan dini adalah pengetahuan orang tua, faktor teman sebaya, dan efikasi diri, dan remaja yang memiliki pengaruh teman sebaya rendah dan memiliki efikasi diri tinggi lebih baik dibandingkan dengan remaja yang memiliki pengaruh teman sebaya tinggi dan efikasi rendah. Menurut Arisjulyanto et al., (2019) remaja yang memiliki pengetahuan tentang perilaku seksual pranikah dan memiliki efikasi tinggi lebih cenderung percaya diri dan tidak gampang terpengaruhi, sehingga lebih kecil kemungkinan untuk melakukan perilaku seksual pranikah yang dampaknya akan menyebabkan kehamilan diluar nikah dan pernikah dini.

Dalam mengatasi masalah ini pentingnya pemerataan pelayanan dan pemanfaatan teknologi sebagai sarana edukasi tambahan dan pusat literacy bagi remaja terkait kesehatan, seperti yang diungkapkan oleh Pasaribu, Arisjulyanto, \& Hikmatushaliha (2018) 
Indonesia merupakan suatu negara berkembang dengan banyak masalah dan tantangan dalam bidang kesehatan, baik dari masalah penyakit maupun kesenjangan dan ketidakmerataannya fasilitas dan pelayanan kesehatan. Mengatasi masalah ini dengan pemanfaatan teknologi dalam kesehatan merupakan langkah tepat dalam pemecahan masalah di bidang kesehatan khusunya masalah pengetahuan tentang kesehatan remaja, perlu dilakukan pengembangan pelayanan kesehatan berbasis telemedicine, dan merupakan salah satu solusi pelayanan kesehatan yang merata dan bisa menyentuh semua kalangan khususnya remaja.

\section{Kesimpulan}

Ada perbedaan tingkat pengetahuan remaja tentang bahaya pernikahan dini sebelum dan sesudah diberikan pendidikan kesehatan sebesar 10,62 dengan $p$ value $0,00<0,05$, yang menyatakan ada pengaruh pendidikan kesehatan terhadap tingkat pengetahuan remaja tentang bahaya pernikahan dini.

\section{Daftar Pustaka}

Arisjulyanto, D., Ismail, D., \& Fuad, A. (2019). Intensity of Social Media Use With Premarital Sexual Behavior Of Adolescents In Smk 2 Gerung West Lombok. Universitas Gadjah Mada.

BKKBN. (2017). Remaja Bonus Demografi. Jakarta.

BPS. (2017). Survey Data Penduduk Indonesia Tahun 2017. Jakarta.

Bulahari, S., \& Korah, H. (2015). Faktor-Faktor Yang Mempengaruhi Pengetahuan Remaja Tentang Kesehatan Reproduksi. JIDANJurnal, 3(2), 15-20.

Finan, L. J., Zhang, L., Paschall, M. J., \& Bersamin, M. (2018). Cognitive precursors to adolescents' reproductive health: Exploring the role of school-based health services. Preventive Medicine, 116(February), 75-80.

Kusmiran, E. (2014). Kesehatan Reproduksi Remaja dan Wanita. Jakarta: Salemba Medika.

Madinah, S., Rahfiludin, M. Z., \& Nugraheni, S.

\begin{abstract}
A. (2017). PENGARUH PENDIDIKAN KESEHATAN REPRODUKSI TERHADAP TINGKAT PENGETAHUAN TENTANG PENDEWASAAN USIA PERKAWINAN (Studi pada Remaja di SMP NU 06 Kedungsuren Kabupaten Kendal). Jurnal Kesehatan Masyarakat, 5(1), 332-340.
\end{abstract}

Minguez, M., Santelli, J. S., Gibson, E., Orr, M., \& Samant, S. (2015). Reproductive health impact of a school health center. Journal of Adolescent Health, 56(3), 338-344.

Pasaribu, K. F., Arisjulyanto, D., \& Hikmatushaliha, B. T. (2018). PENGEMBANGAN TELEMEDICINE DALAM MENGATASI KONEKTIVITAS DAN AKSESIBILITAS PELAYANAN KESEHATAN. Berita Ilmu Keperawatan, 34(11).

Ramos, M. M., McGrath, J., Sebastian, R. A., Stumbo, S. P., Fairbrother, G., \& Sebastian, R. A. (2017). Measuring Unmet Needs for Anticipatory Guidance Among Adolescents at School-Based Health Centers. $J$. Adolescent Health, 60(6), 720-726. 6.12 .021

Rizki, N. aditya. (2012). Motode Focus Group Discussion dan Simulation Game Terhadap Peningkatan Pengetahuan Kesehatan Reproduksi. Jurnal Kesehatan Masyarakat, 8(16), 23-29.

Salih, N. A., Metaferia, H., Reda, A. A., \& Biadgilign, S. (2015). Premarital sexual activity among unmarried adolescents in northern Ethiopia: A cross-sectional study. Sexual and Reproductive Healthcare, 6(1), 9-13.

Sihite, P., Nugroho, D., \& Dharmawan, Y. (2017). Pengaruh Edukasi Kesehatan Reproduksi Terhadap Pengetahuan Siswa Tentang Triad KRR(Seksualitas, HIV/AIDS, Dan Napza) Di SMK SWADAYA KOTA SEMARANG Tri Wulan II tahun2017. JKM UNDIP, 5, 237246.

Suryoputro, A., \& Widjanarko, B. (2016). 
Terakreditasi Peringkat 5 (No. SK: 85/M/KPT/2020)

Perilaku Seksual Remaja di Lingkungan Lokalisasi Kabupaten Sidoarjo, 11(1), 7892.

Umaroh, A. K., Kusumawati, Y., \& Kasjono, H. S. (2015). Hubungan antara faktor internal dan eksternal dengan perilaku seksual pranikah remaja indonesia. Jurnal Kesehatan Masyarakat Andalas, 10, 65-75.

Yulfitria, F. (2017). Pengaruh Pendidikan Kesehatan Dalam Meningkatkan Pengetahuan Tentang Pencegahan Keputihan Patologis, 3(02), 82-92. 